\title{
Plot of Fitzgerald's the Great Gatsby
}

\author{
Ni Gusti Ayu Widiantari ${ }^{1}$, I Nyoman Kardana ${ }^{2}$, AA Ngrh Dharma Prima Sugihantara ${ }^{3}$ \\ Universitas Warmadewa Denpasar-Bali, Indonesia ${ }^{1,2,3}$ \\ \{ikardana@yahoo.com² $\}$
}

\begin{abstract}
This study aimed at analyzing the plot structure and the style used in the novel The Great Gatsby. The theories applied are Freytag's Technique of the Drama written by Gustav Freytag (1896) and supporting theory entitles How to Analyze by Kenney (1966). The method used in this study is a descriptive qualitative, which aims at analyzing and collecting data from some referential books, website, library and other data sources that were useful for the analysis. The source is in the form of a novel that was taken from The Penguin Book: The Great Gatsby, by F.Scott Fitzgerald. As a result of analysis, it shows that there are five structures of the plot (i) exposition is when the narrator introduces the setting that is in New York, West Egg and East Egg, the main characters like Jay Gatsby, Daisy, Tom, and the Narrator Nick. (ii) the conflict happens when Tom and Gatsby argue in the hotel. (iii) the climax happens when Daisy kills Myrtle by Gatsby's car. (iv) failing action is when Gatsby killed by George Wilson, (v) the end of the story is when there is no one attend Gatsby's funeral and Nick moves back to West Egg. Briefly, the style used by F. Scott Fitzgerald uses adjectives in order to create romantic sensation and visualize the story and also imagery to engage all five of the reader's senses so that they cannot only see, but hear, smell, taste, and feel what the characters are experiencing.
\end{abstract}

Keywords: Plot; Style; The Great Gatsby

\section{Introduction}

The novel represents the ideology, attitudes of the author's on certain issues in society. Therefore, the author intends to provoke the readers towards certain human behaviour in society and to understand more about the phenomenon happens to make sense of their worlds. There are two prominent aspects that build up a novel, namely intrinsic and extrinsic elements. Intrinsic elements are elements that directly build up the story in a novel. Those are theme, plot, characters, setting, point of view, and style. Meanwhile, extrinsic element is portrayed as the elements that externally affect the story in a novel. It sees the relationship between literature with the environment like the history, economy, social, and political that can indirectly affect the story in a novel. One of the most important elements of a novel is the plot. The plot is an essential part of the story because by understanding the plot, the readers will be able to understand the work comprehensively. Plot as a significant event in a given story [1]. There are five parts of plot namely exposition, rising action, climax, falling action, and denouement [2].

One of the greatest novels in the modern era is a novel written by F. Scott Fitzgerald, The Great Gatsby. The novel was published in April and it became a critical success and became 
his greatest novel. Many critics agree that this is his best novel. The Great Gatsby is Fitzgerald's best novel on the grounds that here the congruity of story and style and disposition is nearest and generally important. Here, he had a story whose focal character represented his own contentions and disarrays, yet he made a moving analysis on a period and a nation too.

The Great Gatsby is a masterwork in American literature and it is entirely justified. The Great Gatsby is far more complex than just a love story. It presents a complex network of plot twists which is seen from the point of view of Nick Carraway. The style of the author, F. Scott Fitzgerald captures deep emotions and imaginative images. The story illustrates the life of corruption, social class gap, superficial behaviours, and many more. The story happened in New York, Long Island is known as Egg of West and Egg of East.

Judging from the fact that Fitzgerald lived and experienced life in the Jazz Age, his novel has been interested in a sociolinguistic aspect of people in that era. With the attention of the complexity of its plot and the beauty of Fitzgerald's styles in using his voice to make Gatsby as a tragic symbol of the American Dream, the writer inspired to analyze those intrinsic elements of the novel. Previously, this study has been conducted [3] entitled "Plot Analysis of Short Story "Friends Forever" by Aditi Das Bhowmik". Their results showed that the plot short story by Aditi Das Bhowmik is progressive and The structure of plot in friends forever by Aditi Das Bhowmik is exposition, rising action, conflix, climax, falling action and resolution. Furthermore, [4] the similar study entitled An Analysis on the Plot of Jane Austens Novel "Pride and Prejudice" demonstrated that (1) clash on which the plot turns, (2) boss scenes or episodes that make up the plot, and (3) plot as far as its work, inconvenience, emergency/peak, falling activity and end result. Clashes in the novel are pleasantly to peruse and the improvement of the contentions is smooth. Goal is given in an immediate manner. Boss scenes that developed the contention comprise of 15 functions from which the closure of the contentions are effectively to figure however pleasantly to follow. At long last, plots that make up the story brief, smooth, and intriguing are upheld utilizing straightforward exchanges, discussions, and conceivable goal. Thus, the present study aims at analyzing the intrinsic elements of a novel by focusing on plots and the style used by the author in the novel The Great Gatsby.

\section{Methods}

In this study, a descriptive qualitative used to analyze and expose the obtained data. The object of this study is the plot and the style in F. Scott Fitzgerald's The Great Gatsby. The source is in the form of a novel that was taken from The Penguin Book: The Great Gatsby, by F.Scott Fitzgerald. Further, library research is also used to gather and analyze information in academic research which aims at analyzing and collecting data from some referential books, website, and other data sources that were useful for the research. To collect the data, the research used library research study, meanwhileto analyze the data, the researcher did some steps, including: (1) identifying events in the texts, (2) listing the events relevant to problems, (3) finding the conflict that build up the story, (4) looking at the story in terms of the structure of the plot (composition, confusion, peak, falling activity and conclusion), (5) looking for the plausibility of plot by finding chance and coincidence, and (6) finding the conclusion. 


\section{Result and Discussion}

In the novel The Great Gatsby, there are several themes and motifs, namely wealth, dreams, hope, paradox, the American Dream, corruption, self-discovery, reality vs illusion, possession, jealousy, class, love, memory, gender, education, and compassion. Those are some main themes of the novel The Great Gatsby are depicted in every chapter of it. This novel is divided into nine chapters. The first four chapters provide the introduction of the story, the fifth chapter as the climax. Then, the rest of the chapter is the tragic conclusion of the story. In this novel, Nick Carraway is the person who narrates the story, in which he also involves in the actions of the story. As mentioned previously, this study aimed at analyzing the plot structure and the style used in the novel The Great Gatsby. Thus, based on analysis, it was derived the discussion as follows.

\subsection{Beginning}

The beginning is depicted as the introduction of characters, background, settings, and their situations and given important information that enables the reader to follow the story. In this part, there are four important components of the beginning in The Great Gatsby novel namely the exposition of setting, the exposition of events, the exposition of the main characters in the story, and also the brief description of style used by the author.

\section{a) Exposition of Setting}

Exposition of setting is the introduction of the setting in the story. In this case, the setting is defined as the environment or surrounding anything. The exposition of setting in this novel is in the early 1920s in Long Island, New York City in two areas named "West Egg" and "East Egg". Gatsby and Nick live in the West Egg and Daisy's and Tom's house is in East Egg. It can be seen as follows.

Twenty miles from the city a couple of huge eggs, indistinguishable in form and isolated simply by a politeness cove, stick out into the most tamed assortment of saltwater in the Western Hemisphere, the incredible wet farm of Long Island Sound. (Fitzgerald, 1925:7).

Based on the illustration above, the author depicts the situation of the narrator, Nick Carraway's rented house in the North of America. This description portrays the introduction of the setting in general that is in New York and the introduction of the parts of it. Those are Egg of West and Egg of East. Moreover, the narrator begins the story by introducing the place of his living that is in West Egg. It can be seen as illustrated below.

I lived at West Egg, the-well, the less fashionable of the two, though this is a most superficial tag to express the bizarre and not a little sinister contrast between them (Fitzgerald, 1925:7).

Based on the quote above, it portrays the precept of situation that Nick lives. He portrays the modest situation of the West Egg which quite different from the other places in the other parts of New York.

\section{b) Exposition of Event}

Exposition of the event presents the introductory incident that built up the story. Some events are commonly presented in the beginning to introduce the basic event that will connect to other chronological events. 


\section{c) Introduction of Gatsby}

Gatsby is the main character in the novel. The introduction of Gatsby plays an important role because the centre of the story is him. At the beginning of the story, Gatsby is depicted as the mysterious neighbour for Nick Carraway. The introduction of Gatsby is illustrated as follows.

... what's more, I was taking a gander at a rich youthful harsh neck, one or two more than thirty, whose intricate custom of discourse simply missed being silly. At several point before he presented himself I'd got a solid impression that he was pick up his words with handle (Fitzgerald, 1925:53).

Based on the illustration above, it can be seen that it is the first time of the narrator seeing his mysterious neighbour, Gatsby. This event is the main introduction of how the narrator, Nick Carraway meets the main character in this story, Jay Gatsby.

\section{d) Tom has an Affair with Myrtle}

The second important event happens in the story when Nick Carraway figure out that Tom, his cousin's husband has an affair with a woman named Myrtle. This event is illustrated as follows.

So Tom Buchanan and his young lady and I went up together to New York-or not exactly together, for Mrs Wilson sat circumspectly in another vehicle. Tom conceded that a lot to the sensibilities of those East Eggers who may be on the train (Fitzgerald, 1925:30).

Based on the description above, the second event of the beginning of this story is when Nick Carraway is invited by Tom to attend his party with his mistress in his apartment.

\section{e) Reunion of Gatsby and Daisy}

The second major event in the novel The Great Gatsby is one of the significant events. It is because Gatsby's purpose in life is to meet Daisy. His life always wants to be reunited with Daisy. His struggle for being rich is to get Daisy's back. This reunion is one of the major events that can be illustrated as follows.

For a large portion of a moment there was anything but a sound. At that point from the front room, I heard such a stifling mumble and part of a giggle followed by Daisy's voice on an intelligible fake note. 'I unquestionably am terribly happy to see you once more.' An interruption; it suffered horrendously. I didn't have anything to carry out in the lobby so I went to the room (Fitzgerald, 1925:92).

Based on the description above, it shows how the three main characters meet each other. It is because of Nick Carraway, he arranged the time in order to make Daisy and Gatsby can talk and be together in his house.

\section{f) Exposition of Main Character' Details}

Jay Gatsby is the main character in the novel The Great Gatsby. In the beginning, Jay Gatsby is portrayed as a mysterious man, whom everybody talks about. It can be illustrated as follows.

I listen from a man that thoroughly understood him, grew up with him in Germany,' he guaranteed us decidedly. 'Gracious, no,' call the main young lady, 'it couldn't be that, since he was in American armed force while the battle.' As our credulity exchanged back to her she 
inclined back with energy. 'You take a gander at him at times since he believes no one's taking a gander at him. I'll wager he murdered a man. '(Fitzgerald, 1925:48).

This portrays the thought to the narrator, Nick Carraway that Gatsby is an enigmatic figure. He owns a mansion, he holds parties in which the guests spill out onto his lawn and yet nobody knows him.

\subsection{Middle}

In this part, the middle of the story presents the core events. The central events or the main characters will develop in this phase. Generally, the middle consists of three important phases, precisely, conflicts, complication, and climax.

\section{a) Conflicts}

In this phase, there are several clashes of action, ideas, desires, or will. This is a phase when there are some conflicts happen arise between the characters. In this phase there is the situation in which the character's incidents are leading to the hot situation.

In story fiction of The Great Gatsby, the rising action is started with initial complication when Nick visits his cousin Daisy in East Egg. At dinner, there is a tense situation when Tom is always with his phone with someone that makes Daisy angry. It can be seen in the following part of the novel below.

The phone is ring inside, startlingly, and as Daisy shook her head definitively at Tom as subject of the corrals, indeed, all kinds, evaporated into the air. Between the wrecked sections of the most recent five minutes at table I recollect the candles being lit once more, senselessly, and I was aware of needing to take a gander at each one but then to dodge everyone's eyes. I was unable to think about what Daisy and Tom were thinking however I question if even Miss Baker who appeared to have aced a specific solid wariness was capable completely to put this fifth visitor's abrasive metallic desperation out of brain. To a specific personality the circumstance may have appeared to be charming-my own nature was to phone promptly for the police (Fitzgerald, 1925: 19).

\section{b) Complication}

The complication is when there is a crisis moment that leads to a crisis situation. In a complication, the characters or situation enter into and twist the main thread of the plot. In the novel The Great Gatsby, the moment when Tom and Gatsby argue is the moment when there is a complication. They, Tom, Daisy, Gatsby, Nick, and Jordan go to the Baltimore Hotel in New York City. In the hotel, Tom and Gatsby always argue. Tom always wants to show to Daisy that Gatsby is a poor man that is not proper for her. However, Mr Gatsby starts to revenge the mock by saying that Daisy never loves tom. It can be seen in the following illustration.

'I need to realize what Mr Gatsby needs to let me know.'

'Your better half doesn't adore you,' said Gatsby. 'She's never adored you. She cherishes me.' 'You should be insane!' shouted Tom naturally. Gatsby sprang to his feet, distinctive with energy. 'She never adored you, do you hear?' he cried. 'She just wedded you since I was poor and she was burnt out on sitting tight for me. It was a horrible error, yet in her heart, she never adored anybody aside from me!' (Fitzgerald, 1925:139)

Tom mocks Gatsby continuously until he loses his temper. Gatsby approach Tom with anger look like he wants to kill him. It makes Daisy afraid of Daisy. 


\section{c) Climax}

The climax is the phase of the crises comes to its point which has its greatest intensity. Commonly, the climax appears after intriguing conflicts and cannot be solved at the moment and reach its highest point problem. In the novel The Great Gatsby, the climax of the story is when Daisy hit his husband's mistress, Myrtle Wilson, on the way home to East Egg. Daisy does not stop her car and keeps speeding down the road. Myrtle is dead. The situation of Myrtle's dead is illustrated as follows.

The body of Myrtle Wilson enveloped by a cover and afterward in other cover like she experienced a chill in the darkt night lay and work on table by the divider and Tom, with his back to us, was twisting around it, unmoving. Close to him stood a bike cop bringing down names with much perspiration and revision in a little book. From the outset, I was unable to discover the wellspring of the high, moaning words that repeated loudly through the exposed carport-at that point I saw Wilson remaining on the raised edge of his office, influencing to and fro and holding to the doorposts with two hands (Fitzgerald, 1925:148).

\subsection{Ending}

The end of the story is also called as denouement. It is the outcomes of the conflicts situation. This shows how the story ended. It commonly explains how the story ends, what happens to the main character, what is the message of the story. In the novel The Great Gatsby, Fitzgerald portrays the tragic death of Gatsby. After knowing his wife is dead, George Wilson thinks that the killer must be her lover. He then tries to figure out who it was. He comes to Tom for help. Tom then finally tells that it was Gatsby's car who hit Myrtle. Therefore George kills Gatsby with his anger and also kills himself. The following illustration is in chapter 8 when Gatsby's body floating in the pool.

I have a thought that Gatsby himself didn't trust it would come and maybe he did not mind anymore. In the event that that was genuine he probably thought that he had lost the old warm world, addressed a significant expense for a really long time with a solitary dream. He more likely than not gazed toward a new sky through startling leaves and shuddered as he found what a peculiar thing a rose is and how crude the daylight was upon the hardly made grass (Fitzgerald, 1925:172).

The author's style in the end, still shows how strong the use of adjectives by Fitzgerald. Another example of the use of adjectives that shows his style can be seen on page 132. It is illustrated as follows:

In any case, his heart was in a consistent, fierce mob. The most unusual and fabulous arrogances frequented him in his bed around evening time. A vast expanse of unspeakable pretentiousness spun itself out in his cerebrum while the clock ticked on the wash-stand and the moon doused wet light his tangled garments upon the floor. Every night he added to the example of his likes until sleepiness shut downward on some distinctive scene with a neglectful grasp. (Fitzgerald, 1925:132)

From the quote above, there are some constant adjectives used by Fitzgerald such as constant, turbulent, grotesque, fantastic, ineffable, tangled, each, vivid, and oblivious. In the passage above, there is more than $10 \%$ of the total number of those adjectives. It shows that Fitzgerald describes the situation which has nothing to do with physical attributes. 


\section{Conclusion}

Regarding the previous analysis and the objectives of the study, it can be concluded that the novel The Great Gatsby, the principal part is the fortune. Therefore, this novel is categorized using the plots of fortune. Fitzgerald depicts a tragic impression in which at the end of the story, there is the tragic death of three main characters, Gatsby, Myrtle, and George. Moreover, Gatsby fails in getting Daisy's back. Therefore, it uses tragic plot. The structure of the plot is (a) Exposition: the introduction of the narrator Nick Carraway to introduce the setting in New York, Egg of West, Egg of East, and Long Island. It is also introduced the character like Gatsby, Daisy, Tom, Jordan Barker, Myrtle, and Mr Mrs Mc Kee. (b) Rising Action: Daisy conflicts with his husband, Tom in the dinner when Nick knew he has a mistress. Moreover, there is a conflict between Tom and Myrtle, his mistress in his rental apartment. It is also the moment when Tom and Gatsby argue is the moment when there is a complication. They, Tom, Daisy, Gatsby, Nick, and Jordan go to the Baltimore Hotel in New York City. (c) Climax: it is when Daisy hit his husband's mistress. (d) Failing Action: The death of Gatsby and George Wilson. (e) Denouement: no one comes to Gatsby funeral and Nick Carraway goes back to West Egg.

\section{References}

[1] A. Dibell, Freytag's Technique of the Drama. The University of Illinois Library, 1988.

[2] G. Freytag, Freytag's Technique of the Drama. The University of Illinois Library, 1896.

[3] A. S. Ridho, P. Rahayu, and A. Donal, "Plot Analysis of Short Story 'Friends Forever' By Aditi Das Bhowmik," e-Journal Mahasiswa Prodi Bahasa Inggris, vol. 2, no. 1, 2016.

[4] Arbain, "An Analysis on the Plot of Jane Austens Novel 'Pride and Prejudice," Lingua, vol. 13, no. 1, pp. 127-142, 2016. 